\title{
Mediation and peacebuilding in Tunisia: actors and practice
}

Alex Walsh ${ }^{1}$ and Hamza Ben Hassine ${ }^{2}$

8 April 2021

\section{Questions}

- Which government and non-government institutions and civil society actors in Tunisia are able to mediate conflict or facilitate peacebuilding at a local and/or national level?

- How has their role and capacity changed over time?

- How does gender shape roles and capacities?

- What does this look like in practice? With regards to:
a. Human rights
b. Women's rights
c. Economic rights and natural resources

\section{Contents}

1. Overview

2. Trends in mediation and peacebuilding in Tunisia

3. Mediation and peacebuilding in practice

4. References

5. Annex A. Organisations involved in Peacebuilding and Mediation

\section{${ }^{1}$ Coordinator, Algerian Futures Initiative \\ ${ }^{2}$ Independent Researcher}

The K4D helpdesk service provides brief summaries of current research, evidence, and lessons learned. Helpdesk reports are not rigorous or systematic reviews; they are intended to provide an introduction to the most important evidence related to a research question. They draw on a rapid desk-based review of published literature and consultation with subject specialists. 


\section{Overview}

This Helpdesk Report is part mapping of the mediation and peacebuilding actors in Tunisia and part review of the available literature. There are a host of governmental and non-governmental organisations (NGOs) that are involved in mediation of conflicts and peacebuilding, both in formal and informal ways. Annex A comprises a table describing these organisations.

There is overlap in the principles and goals of peacebuilding and mediation; many organisations conduct both practices, intermingling them. Local, regional, national and international actors have applied mediation and peacebuilding to many different types of conflict in the past decade in Tunisia, involving varied parties. The case studies included in this rapid review cover conflicts relating to labour and the economy, the environment, basic services, constitutional/political disputes, and women's rights. They involve local communities, the unemployed national and regional trade unions, civil society organisations (CSOs), national utility and mineral companies, and political parties.

On the basis of the literature identified, it is difficult to be categorical or evidenced about the growth or otherwise of mediation and peacebuilding as a practice. However, there are fair indications that these practices have become more widespread, and indeed more prominent on the national scale. It also appears possible that the capacity of women in this regard has grown.

The literature identified does not treat the questions of capacity and role particularly directly and so this indication is drawn largely from the programmatic publications of international NGOs and their local counterparts. This points to two possible distortions in the findings about capacity and roles - the first may be an overemphasis on internationally-supported mediation and peacebuilding efforts structured within formal projects and programmes, to the detriment of the more informal, non-reified, non-publicised and local work of everyday mediation and peacebuilding. Proceeding from this is the second possible distortion, which would be inflation of the growth of capacity effected by such programmes; indeed the finding of 'growth' assumes a degree of positive impact affected by international efforts. With this in mind, it can at least be stated that there has likely been an increase of resource and publicity devoted to capacity building in Tunisia. These limitations should be remembered when examining the table in Annex A.

This potential limitation of the material finds a parallel in a critique of international peacebuilding efforts in Tunisia and across the globe (Richmond, 2011). This critique claims that international NGOs tend to favour large and well-established institutions over smaller, less formal ones. An allied critique highlights that internationally sponsored 'liberal peacebuilding' efforts have militated against Tunisia's revolutionary agenda in certain ways.

The material used for this report was drawn from Arabic, English and French publications and was largely gender blind. 


\title{
2. Trends in mediation and peacebuilding in Tunisia
}

\author{
Mediation and peacebuilding compared
}

\begin{abstract}
"Mediation is negotiation facilitated by a trusted neutral person" (International Mediation Institute, n.d.). It is an impartial, confidential, non-binding attempt to reach a commonly constructed and mutually acceptable solution. In legal disputes, its common advantages over litigation are lower costs and more generally it is less confrontational and has a capacity to transform relationships, as well as resolve problems. Mediation is a practice that is highly intentional around process, where parties have an opportunity to reflect on their needs and interests and their positions towards the conflict and towards the other party. It is therefore a practice with a straightforward definition and an application to a wide range of disputes and conflicts, involving varied parties and mediators. This rapid review uses a broad notion of mediation, including mediation that is legally framed and those that proceed more casually, based on norms or ad hoc arrangements. There is legal provision requiring mediation in certain circumstances (see 'The legal framework of mediation) and, as the case studies show, is more ad hoc mediation is widely used to tackle disputes with varied causes and different levels.
\end{abstract}

Peacebuilding is harder to pin down in terms of practice and principles than mediation. Its definition is the subject of contention, but broadly its goal is addressing the root causes of conflict while supporting nationally and locally generated ways of transforming those causes into factors more conducive to a just and equitable relationship between parties, communities and populations as a whole; it also seeks to prevent the relapse of conflict (UN Peacebuilding Support Office, 2010).

Within this broad definition, the goals of peacebuilding and mediation overlap. Furthermore, much like mediation, peacebuilding is built emphatically around process, being about 'how' the process is followed as much as about 'what' is done, with a strong commitment to conflict sensitivity, inclusion of marginalised groups and women's participation among other principles (UN Peacebuilding Support Office, 2010). This overlap is visible in Tunis, where peacebuilding projects have also included direct support to mediators and other types of facilitators - as with the United States Institute of Peace's support to the Alliance of Tunisian Facilitators (ATF) (USIP, n.d.). Indeed, in several notable cases, such as promoting inclusive dialogue during the national constitutional crisis of 2014, or in labour disputes in el-Kamour in June 2017 (see Section 3: 'Mediation and Peacebuilding in practice'), uses of peacebuilding and mediation are difficult to disentangle.

One important difference, however, is that peacebuilding's activities can be more diverse than those of mediation. In principle and in practice in Tunisia, peacebuilding can go beyond the structured negotiation of mediation. Peacebuilding activities include raising ecological awareness (UNESCO, 2020), empowerment of youth (UN Volunteers, 2020) as well as building understanding between religious groups, community theatre and dialogue promotion.

\section{The legal framework of mediation}

Mediation as a practice in many jurisdictions has authority based on the law. In Tunisia, there is no general legal framework governing mediation in Tunisia (Souilah, 2021), but there are a number of legal texts that provide for mediation as a non-litigious or non-adversarial legal settlement. This situation is described by el-Abid (2017): 
1. District Courts' judges are to request parties explore an amicable agreement before any adversarial proceedings begin (CCPC, Art.45).

2. In any divorce settlement, sessions of judicial settlement are mandatory (Family Law Code, Art.32).

3. In any labour dispute, there is a requirement for an attempt at an amicable procedure (Labour Code, Art.207) and in which case, the president of a commercial chamber can mandate one of the chamber's members to support the parties come to an amicable settlement (CCPC).

There are also particular laws governing sectors allowing for mediation for dispute resolution in specific sectors, including (el-Abid, 2017):

1. Financial institutions (including banks) are required to appoint one or more mediators who can review claims brought by clients (Law No.2006-19, modifying Law No.200165).

2. The mediator for state administration of public services (established by Decree 10.12.1993) has had their powers expanded (Law No.51 No.1993), and is charged with maintaining the rights of citizens in their quotidian business with the state when the state violates laws or regulations or is excessively delayed.

There was no material identified by this rapid review illustrating such cases of legally authorised mediation in the literature, and it is assumed that the case studies provided below in Section 3 proceeded on an ad hoc basis.

\section{Developments in role and capacity}

Although the available literature and published material does not speak directly to the changing role and capacity of mediation and peacebuilding, there are some indications of their growth. ${ }^{3}$ This can be seen in the additions to the legislation concerning mediation in the 2000s, listed previously. And, despite a low number of qualified mediators and a lack of a general legal framework (Souilah, 2021), there may be an "embryonic mediation market" in Tunisia, given that the Bar Association is attempting to raise awareness of its benefits (el-Abid, 2017). There was no data more recent than 2017 identified to corroborate this.

Furthermore, as part of the considerable growth in international development engagement with Tunisia in period after the 20211 Arab Spring, there are many instances of internationally sponsored programmes supporting mediation and peacebuilding at the local, regional and national level. Assuming some degree of impact is being made, this suggests that mediation and peacebuilding capacity is growing. For example, the USIP intervention with the ATF showcases several cases of the work of mediation and peacebuilding since 2014. In one instance, in Douar Hicher - a community affected by high levels of extremist recruitment - ATF and USIP helped empower local women to build peace in a troubled community, including through breaking the taboo of discussing radicalisation. Other cases cover socio-economic disputes in Tataouine, relations between youth and security forces in Medenine, and municipal

\footnotetext{
${ }^{3}$ The Centre de conciliation et d'arbitrage de Tunis (CCAT) has been carrying out commercial arbitration since 1996, in addition to conducting training and organising colloquia (CCAT, 2021). Arbitration is a different but related process to mediation.
} 
governance in Ben Guerdane (USIP, n.d.). The ATF has also been involved in reducing the chances of disputes around state assistance during the COVID-19 pandemic by supporting access by vulnerable groups (USIP, n.d.). Figure 1 illustrates locations where the ATF has intervened. Search for Common Ground (SFCG) has also been running peacebuilding programmes since 2013, including empowering youth to participate in politics (Zehra, 2019).

Peacebuilding as an international development approach is not without its critics. Critical scholarship claims that international development organisations do not distribute this capacity building support evenly across Tunisian civil society (Letsch, 2018) They have tended to favour "well-established professionalised NGOs at the expense of more locally rooted small-scale associations within existing initiatives" (Letsch, 2018, p.166). This is part of a broader, global critique of international support to peacebuilding that claims that international assistance can lead to the creation of an artificial civil society that is disconnected from national and local needs (Richmond, 2011). In reference to developments across the Arab World since 2011, Pogodda (2020) points out incompatibilities between liberal peacebuilding interventions and revolutionary agency. In very simplified terms, liberal peacebuilding efforts are designed to import western governance models and liberalise economies, including the involvement of hierarchical political parties and the reliance on civil society groups to overcome marginalisation. Conversely, many revolutionary actors in Tunisia espouse a leaderless, networked and more direct political participation, including mass street mobilisation, and frustrated with the reject international peacebuilding efforts as a form of neo-colonialism.

\section{Gender developments}

The identified academic and grey literature about the capacity and role of women in peacebuilding and mediation, and the general place of gender therein, is limited. However, a tendency to promote the role of women can be construed from the published material of multilateral and international organisations. One training session delivered in 2017 targeted women judges in a session entitled 'Mediation: another way to resolve conflicts, another culture'. This training session covered the legislative and normative framework, judicial mediation and family mediation (International Association of Women Judges, 2019).

There have also been specific initiatives to enhance the role of women in peacebuilding in Tunisia. In 2018, Tunisia adopted a National Action Plan for UN Security Council Resolution 1325 on women, peace and security. The Action Plan promotes the role of women and girls in preventing risks of conflict and violent extremism, eradicating gender-based violence and ensuring stable and durable peace (UNDP, 2020). Internationally supported projects have sought to propel the Action Plan, for instance, the PARFAIT project, aiming to promote women's participation in politics in Gafsa, Grand Tunis, Jendouba, Kairouan, Kebili and Mahdia (Rouhshahbaz, 2020). In political life, women have a played an important role in the developments post-2011, including in the constitutional assembly and the legislature - and, as of 2018 , women made up $47 \%$ of local council positions in Tunisia and $43 \%$ of trade union membership (Smith, 2019). During the constitutional crisis of 2013-2014, which could have had catastrophic consequences, businesswoman Wided Bouchamaoui was part of the National Dialogue Quartet that facilitated a resolution and received a Nobel Peace Prize in 2015; she later became the first woman to lead the employer's union (UTICA the Union tunisienne de l'industrie, du commerce et de l'artisanat) (Smith, 2019). 


\section{Indicative findings}

Overall, it is difficult to make categorical and evidenced claims about the growth in capacity and prominence of peacebuilding and mediation. These findings on the growth of mediation and peacebuilding in Tunisia should therefore be considered indicative. Although they appear likely to reflect internationally sponsored mediation and peacebuilding efforts that are accompanied by publicity and online publications, they may be blind to more local, non-reified and more informal efforts. However, the published material as it exists points to a growing capacity and salience. The work of the National Dialogue Quartet in 2013-2014, which may have saved Tunisia from violent conflict, is the highlight of mediation and peacebuilding in Tunisia in the last decade and if not before. It is included as a case study in Section 3.

\section{Mediation and peacebuilding in practice}

Case studies were chosen to illustrate the practice of mediation and peacebuilding in Tunisia over a variety of disputes. The case studies range across geographic level - from the local (A), to the regional $(B)$ and the national $(C)$ and are each multi-level in their own way. They cover conflicts with labour, environmental, constitutional/political and women's rights elements. They involve local communities, national and regional trade unions, civil society organisations (CSOs), national utility and mineral companies and political parties. Each of these case studies have explicit and implicit connections to human rights.

\section{Case Study A: An industrial and economic dispute in El Kamour, Tataouine Governorate, 2017}

\section{The dispute}

El Kamour is a town in the Tataouine Governorate, an important transit site for oil and gas; is a region that remains economically disadvantaged with an unemployment rate in 2017 of $36 \%$, rising to $51 \%$ among university degree holders. Communities have long expressed anger at the lack of investment in their area and the lack of employment opportunities, given the industrial activity that generates air and water pollution. From May 2017 for around two months, protestors, including between a few hundred and a thousand young and mostly unemployed men, conducted a sit-in in a hydrocarbon facility (Cherif, 2017). Addressing the Tunisian state, they called for $20 \%$ of regional industrial revenues to be invested in El Kamour, at least 4,500 jobs to be created by extraction companies, and a USD40m state investment for the development of Tataouine (Cherif, 2017). The Regional Union of Workers (URT) in Tataouine, which reports to the Union Générale Tunisienne du Travail (UGTT), has shown its support for the protestors demands since at least March 2017 (Derbali, 2019).

\section{The mediation}

The government requested that the UGTT mediate to find a solution, a role that protestors reportedly accepted on the whole on account of the UGTT's generalised legitimacy (Dubessey, 2020). In mid-June 2016, the government signed a deal with the protestors, envisaging inter alia a development plan worth TND 40m (c.USD 29 million) per year, employment of 1,500 people in the petroleum companies and 3,000 people in the Société Tunisienne pour 
l'Environnement (Derbali, 2019). The process of the mediation and the deal calmed the tense atmosphere in the region.

\section{The outcome}

Many of these promises have yet to be fulfilled. In March 2017, reacting to the slow progress, the UGTT expressed its solidarity with the protestors in a public communication (Business News, 2018). In July 2020, the NGO I Watch stated that only $44 \%$ of the promises comprising the deal had been kept. The president of the UGTT, Noureddine Taboubi, wrote an open letter to the president of the Republic, the prime minister and the speaker of parliament tying ElKamour into the general socio-economic situation of the country. The movement in El Kamour and across the region of Tataouine is again active, with spokesperson Tarek Haded naming UGTT the "union de la ruine" in February 2021 (Webdo, 2021). Protestors also criticised the UGTT for opportunism (Killani, 2020).

\section{Case Study B: A water dispute in Redeyef, Gafsa Governorate, 2019}

\section{The dispute}

The Governorate of Gafsa suffers from water stress and each of its constituent delegations faces regular water cuts. Furthermore, inhabitants of the region found the attitude of the national water distribution company, Société nationale d'exploitation et de distribution des eaux (SONEDE), to be indifferent to their problem, reflecting a string of broken promises (Ben Amor et al., 2019). There were also grievances that large landowners were siphoning away water illegally (Ben Amor et al., 2019). These grievances also mingled with protests against the management of phosphate extraction in Gafsa. Negative side effects for the community include heavy water exploitation for the leaching process and the discharge of untreated wastewater, contaminating water and damaging soil fertility as well as damage to property (Hamouchene, 2019). In 2020, an intentional mining explosion caused serious damage to a residence (Mabrouki, 2020).

An agreement in 2018 between inhabitants, SONEDE and the phosphate mining company (Compagnie des Phosphates de Gafsa, CPG) whereby CPG supported SONEDE in sinking wells, led to an improvement of the water supply. However, in the spring and early summer of 2019, water cuts in Elassala, Elmsabhyè, l'Afran et Cité Essourour led protestors to stage a sitin at SONEDE offices in Gafsa in May 2019. The sit-in blocked the administrative work of SONEDE. Protestors called on CPG to intervene on the basis that they would have the technical capability and influence to ensure the flow of water (Ben Othmane, 2019a \& 2019b).

\section{The mediation}

The Forum Tunisien pour les Droits Economiques et Sociaux (FTDES) engaged with protestors to understand their views and demands. Gafsa Governorate Authorities met with SONEDE. FTDES was consequently invited by the director of the CPG office in Redeyef to discuss matters. 


\section{The outcome}

For around one month, water supply improved and tensions eased. In four meetings between the Gafsa Governorate authorities and SONEDE a deal was made that accelerated works already planned to sink wells at Redeyef, Mthilla and Gafsa city. Two additional new wells were sunk in Tarfaye and Tebeddit, reportedly due to the meeting between FTDES and CPG. However, in late June 2019 , as temperature approached $50^{\circ} \mathrm{C}$, FTDES called for a new protest, which took place for a half day at CPG facilities. The protest call was "Water is the priority for inhabitants and not for phosphate". Water provision difficulties continue in Redeyef and protests took place in 2020, albeit centred more on grievances related to phosphate than water (Arab Weekly, 2020).

\section{Case Study C: The constitutional crisis of 2013-2014}

\section{The dispute}

In the summer of 2013, a serious political crisis arose over the drafting of the Tunisia's new constitution. The Ennahda party held the largest number of seats in parliament and, in a minority position, governed in coalition with the secularist parties Congress for the Republic and Ettakatol. In Spring 2012, a draft constitution proposed by Ennahda enshrined Islam as the official religion of the state (making Islam the moral and cultural basis of the state), which led secularists and the opposition to fear the creeping Islamisation of the state. Criticism was also provoked by the categorisation of women not as "equal" to men but as "complementary". The assassination of leftist politicians Choukri Belaid and Mohamed Brahmi in February and July 2013 heightened tensions (El Amrani, 2017). Regional geopolitical developments - such as the military coup in neighbouring Egypt and the violent competition between regional powers in other Arab countries - seemed to presage a violent denouement. On one side, the UGTT urged for the removal of the tripartite coalition and the establishment of a caretaker government to preserve national unity, while others argued that the removal of a democratically elected government would threaten Tunisia's budding democracy. Polarisation of the political scene hindered dialogue between parties, and after the assassination of Brahmi, the UGTT called a general strike; violent street clashes occurred between security forces and supporters and opponents of the government.

\section{The mediation}

Through an initiative begun by UGTT and consequently supported by UTICA (Tunisian Union for industry, commerce and artisanship), the Tunisian Human Rights League and the National Order of Lawyers, the National Dialogue Quartet was formed. The Quartet was joined by a score of political parties and its composition represented a powerful combination of the political, juristic, industrial and commercial elements of Tunisian society.

\section{The outcome}

The Quartet supported dialogue between political parties, which led to an agreement over a constitution (with most of the Islamist elements withdrawn), and election dates were agreed. The following elections (2014) passed peacefully. Success factors in the mediation included the breadth of the Quartet's sectoral support, its public backing, and the negotiation experience of 
its foremost members and their existing relationships; the maturity of Tunisian civil society was also crucial (OSCE, 2016). The award of the Nobel Peace Prize to the Quartet in 2015 attests to the gravity of national disaster they averted. According to an interview with the Quartet members in 2016, they were requested to institutionalise the dialogue they had started but declined in order to avoid establishing a parallel political process to the democratic processes already in place (OSCE, 2016).

\section{References}

Arab Weekly (2020). Protesters halt phosphate production in Tunisia's mining region. https://thearabweekly.com/protesters-halt-phosphate-production-tunisias-mining-region

Ben Amor, R., Ben Khaled, T., Ben Othmane, R., Gaaloul, M., Jonville, M., Mejbri, M., Ouerd M., (2019). La justice environnementale, un combat continu... Forum Tunisien pour les Droits Economiques et Sociaux, Tunis https://ftdes.net/en/la-justice-environnementale-un-combatcontinu/

Ben Othmane, R. (2019a). فرع الحوض المنجمي للمنتدى: النضال منو اصل من أجل الحق في الماء. (Mining Basin Branch of the Forum: the Continuing Struggle for Water Rights) Forum Tunisien pour les Droits Economiques et Sociaux, Tunis. https://ftdes.net/ar/5555-2/

Ben Othmane, R. (2019b). La lutte continue pour le droit à l'eau potable à Redeyef, revue de la justice environnementale. Forum Tunisien pour les Droits Economiques et Sociaux, Tunis. http://ftdes.net/rapports/Revue-JE-FR-final.pdf

Cherif, Y. (2017). The Kamour Movement and Civic Protests in Tunisia [WWW Document]. Carnegie Endowment for International Peace.

https://carnegieendowment.org/2017/08/08/kamour-movement-and-civic-protests-in-tunisia-pub72774

Derbali, M. (2019). Tataouine: Sit-in d'El Kamour, le réveil d'un volcan. Nawwat. https://nawaat.org/2019/12/31/tataouine-sit-in-del-kamour-le-reveil-dun-volcan/

Dubessy, F. (2020). Les grèves reprennent dans le sud tunisien. Econostrum. https://www.econostrum.info/Les-greves-reprennent-dans-le-sud-tunisien_a26922.html

El-Abid, Y. (2017). Status of Mediation in Tunisia: "Bringing Mediation to Law School" Project' https://www.linkedin.com/pulse/status-mediation-tunisia-bringing-law-school-project-yosra-abid

El Amrani, I. (2015). Tunisia's National Dialogue Quartet Set a Powerful Example [WWW Document]. Crisis Group. https://www.crisisgroup.org/middle-east-north-africa/northafrica/tunisia/tunisia-s-national-dialogue-quartet-set-powerful-example

Hamouchene, H. (2019). Extractivism and Resistance in North Africa. Amsterdam: Transnational Institute. https://www.tni.org/files/publication-downloads/web_maghreb_en_2111-19.pdf. 
International Association of Women Judges (2019). Tunisian Association of Women Judges Conducts Mediation Training. International Association of Women Judges.

http://www.iawj.org/tunisian-association-of-women-judges-conducts-mediation-training/

International Mediation Institute (n.d.). What is Mediation?

https://www.wipo.int/amc/en/mediation/what-mediation.html.

Killani (n.d.). تنسيقية اعتصام الكامور تصف قرار اتحاد الثغل الإضراب العام بالركوب على الأحداث | الثاهد (El Kamour Sit-in Coordination Committee calls out the Labor Union General Strike for Piggybacking on Youth)

https://www.achahed.com/post/\%D8\%AA\%D9\%86\%D8\%B3\%D9\%8A\%D9\%82\%D9\%8A\%D8\% A9-\%D8\%A7\%D8\%B9\%D8\%AA\%D8\%B5\%D8\%A7\%D9\%85-

\%D8\%A7\%D9\%84\%D9\%83\%D8\%A7\%D9\%85\%D9\%88\%D8\%B1-

\%D8\%AA\%D8\%B5\%D9\%81-\%D9\%82\%D8\%B1\%D8\%A7\%D8\%B1-

\%D8\%A7\%D8\%AA\%D8\%AD\%D8\%A7\%D8\%AF-

\%D8\%A7\%D9\%84\%D8\%B4\%D8\%BA\%D9\%84-

\%D8\%A7\%D9\%84\%D8\%A5\%D8\%B6\%D8\%B1\%D8\%A7\%D8\%A8-

$\% \mathrm{D} 8 \% \mathrm{~A} 7 \% \mathrm{D} 9 \% 84 \% \mathrm{D} 8 \% \mathrm{~B} 9 \% \mathrm{D} 8 \% \mathrm{A7} \% \mathrm{D} 9 \% 85-$

\%D8\%A8\%D8\%A7\%D9\%84\%D8\%B1\%D9\%83\%D9\%88\%D8\%A8-

$\% \mathrm{D} 8 \% \mathrm{~B} 9 \% \mathrm{D} 9 \% 84 \% \mathrm{D} 9 \% 89$ -

\%D8\%A7\%D9\%84\%D8\%A3\%D8\%AD\%D8\%AF\%D8\%A7\%D8\%AB

Letsch, L. (2018). Countering Violent Extremism in Tunisia - Between Dependency and SelfReliance. Journal for Deradicalization, 17.

Mabrouki, R. (2020). النشاط المنجمي بالرديف : تفجير الديناميت يدوّي في قلب المنازل (Redeyef Mining Basin: Dynamite explostion reverberates in the heart of homes) Forum Tunisien pour les Droits Economiques et Sociaux, Tunis. . https://ftdes.net/ar/activites-extractives-a-redeyef/

OSCE (2016). Tunisian Quartet in conversation. Organisation for Security and Cooperation in Europe. https://www.osce.org/magazine/248471

Pogodda, S. (2020). Revolutions and the liberal peace: Peacebuilding as counterrevolutionary practice? Cooperation and Conflict, 55, 347-364. https://doi.org/10.1177/0010836720921881

Richmond, O. (2011). A Post-Liberal Peace. Routledge.

Rouhshahbaz, S. (2020). Political Participation, Decentralization and Gender Mainstreaming: the PARFAIT Project in Tunisia. Agency for Peacebuilding.

https://www.peaceagency.org/2020/10/14/political-participation-decentralization-gendermainstreaming-parfait-project-tunisia/

Smith, N. (2019). Women in Tunisia During the Arab Spring: A Case Study for Inclusive Peacebuilding and Gender Reform. Global Affairs Review.

https://gareviewnyu.com/2019/10/22/women-in-tunisia-during-the-arab-spring-a-case-study-forinclusive-peacebuilding-and-gender-reform/

Souilah, M. (2021). Le Législateur Tunisien et la Médiation. https://cim-imc.com/wpcontent/uploads/2021/02/Le-legislateur-tunisien-et-la-mediation.pdf. 
UN Peacebuilding Support Office (2010). UN Peacebuilding: an Orientation.

https://www.un.org/peacebuilding/sites/www.un.org.peacebuilding/files/documents/peacebuildin g_orientation.pdf

UNESCO (2020). Using green entrepreneurship to foster peace in Tunisia: the Story of Sahar, UNESCO. United Nations Educational, Scientific and Cultural Organization.

https://en.unesco.org/news/using-green-entrepreneurship-foster-peace-tunisia-story-sahar.

UNDP (2020). Women, Peace and Security: priorities for implementation 20 years after UN Security Council resolution 1325 and UNDP commitment to making a difference in the lives of people in Tunisia. United Nations Development Programme.

https://www.tn.undp.org/content/tunisia/fr/home/blog/women--peace-and-security--priorities-forimplementation-20-year.html

USIP (n.d.). Alliance of Tunisian Facilitators (ATF) [WWW Document]. United States Institute of Peace. https://www.usip.org/programs/alliance-tunisian-facilitators-atf

Webdo (2021). 'Tarek Haddad: “L'UGTT, l'union de la ruine !'”. Webdo, 24 February. http://www.webdo.tn/2021/02/24/tarek-haddad-lugtt-lunion-de-la-ruine/

Zehra, S. (2019). Transforming Local-National Ties in Tunisia: A Strategy for Strengthening Youth Peacebuilding, Global Affairs Review. The Center for Global Affairs, New York University. https://wp.nyu.edu/schoolofprofessionalstudies-ga_review/transforming-local-national-ties-intunisia-a-strategy-for-strengthening-youth-peacebuilding/

\section{Suggested citation}

Walsh, A., and Ben Hassine, H. (2021). Mediation and peacebuilding in Tunisia: actors and practice. K4D Helpdesk Report 960. Brighton, UK: Institute of Development Studies. DOI:

10.19088/K4D.2021.061

\section{About this report}

This report is based on six days of desk-based research. The K4D research helpdesk provides rapid syntheses of a selection of recent relevant literature and international expert thinking in response to specific questions relating to international development. For any enquiries, contact helpdesk@k4d.info.

K4D services are provided by a consortium of leading organisations working in international development, led by the Institute of Development Studies (IDS), with Education Development Trust, Itad, University of Leeds Nuffield Centre for International Health and Development, Liverpool School of Tropical Medicine (LSTM), University of Birmingham International Development Department (IDD) and the University of Manchester Humanitarian and Conflict Response Institute (HCRI).

This report was prepared for the UK Government's Foreign, Commonwealth and Development Office (FCDO) and its partners in support of pro-poor programmes. Except where otherwise stated, it is licensed for non-commercial purposes under the terms of the Open Government Licence v3.0. K4D cannot be held responsible for errors, omissions or any consequences arising from the use of information contained in this report. Any views and opinions expressed do not necessarily reflect those of FCDO, K4D or any other contributing organisation.

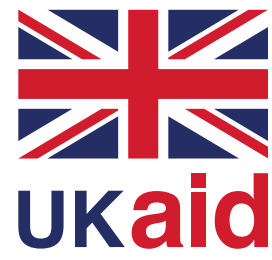

C Crown copyright 2021. 


\section{Annex A. Organisations involved in Peacebuilding and Mediation}

Organisation

Union générale tunisienne du travail (UGTT)

\section{Type}

Description

professionals and

workers
The principal syndicate of Tunisia counting 750,000 members. Composed of 24 regional unions, 19 federations and 21 syndicates.
Instances of

mediation or

peacebuilding

Involved in the negotiations in ElKamour in 2017

\begin{tabular}{|c|c|c|}
\hline $\begin{array}{l}\text { Union tunisienne de } \\
\text { l'industrie, du commerce et } \\
\text { de l'artisanat (UTICA) }\end{array}$ & Employers' syndicate & $\begin{array}{l}\text { Brings together employers from industry, } \\
\text { commerce, services, artisans. Represents } \\
\text { more than } 150,000 \text { private businesses, with } \\
\text { exception of tourism and finance/banking. } \\
\text { Comprises } 17 \text { federations, } 24 \text { regional unions, } \\
216 \text { local unions, } 370 \text { national syndicate } \\
\text { chambers and } 1,700 \text { regional syndicate } \\
\text { chambers.. Seeks to improve the management } \\
\text { of employment disputes in practice, regulation } \\
\text { and law. }\end{array}$ \\
\hline
\end{tabular}

Involved in the establishment and leadership of the National Dialogue Quartet.

\section{L'Association des \\ Ombudsmans et des \\ Médiateurs de la}

Francophonie (AOMF)
NGO

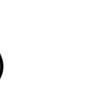

International organization promoting the role of mediators and mediation in the francophone word.
Supports the office of the Administrative 
Mediator of the

Tunisian

Médiateur administratif de la

République tunisienne
Independent, statutory entity
Created in 1993. Mediates disputes between citizen and state over state administration and services.
Conseil national du dialogue social.

Independent, statutory entity
Platform for national consultation on social and economic matters. Comprises representatives of employers, workers/professionals and the state. Seeks to build decent working conditions and respect of social legislation, organizing dialogues.
Met in November 2019 with UGTT, UTICA and Minister of Social Affairs

\section{Deutsche Gesellschaft für}

Internationale

Zusammenarbeit (GIZ)
NGO

Active in Tunisia since 1970. Works on behalf of the Federal Government of Germany and the EU inter alia. Carries out programming in economic development, democracy consolidation with a focus on rural regions, youth, energy transition, environment, and human rights. 
United State Institue of peace (USIP)

NGO
International United States organization, nonpartisan and independent, founded by US Congress.

Works with partners in Tunisia to prevent, attenuate and resolve violent conflict.

Focuses on sustainable social development, governance and civil society.
Set up the Alliance of Tunisian Facilitators and continues training and other support to it. ATF has been involved inter alia in dispute resolution in Tataouine Governorate.

USIP supports the improvement of

relations between communities and the security sector towards institutional reform of the sector.

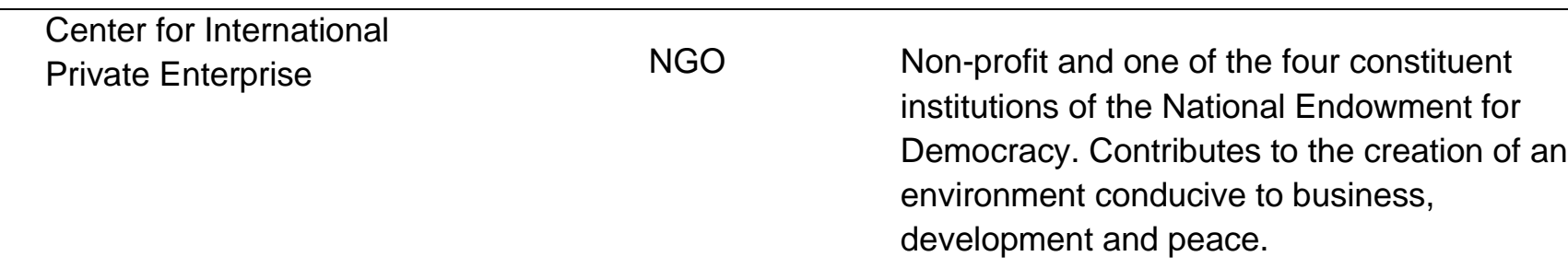


Agence Nationale pour

l'Emploi et le Travail

Indépendant (ANETI)
Non-administrative public entity
Implements state policy on promoting

employment. Placed within the Ministry of

Professional Training and Employment.
Konrad Adenauer Stiftung (KAS)

NGO
Development arm of the German political party the Christian Democratic Union. Works on democratic consolidation, civil society, intercultural dialogue, conflict prevention and EU-neighbourhood relations

\author{
Conducted a \\ quantitative study with \\ Sigma on social \\ dialogue within \\ Tunisian businesses. \\ Followed up with a \\ qualitative study with \\ the Higher School of \\ Commercial Sciences \\ of Tunis which involved \\ representatives of the \\ employers '(UTICA) \\ and workers' (UGTT) \\ unions in 8 companies \\ operating in different \\ sectors. The purpose \\ of these two studies \\ was to develop a guide \\ to good practices in \\ social dialogue
}

$\begin{aligned} & \text { Friedrich Naumann Stiftung } \\ & \text { (FNS) }\end{aligned} \quad$ NGO
$\begin{aligned} & \text { Development wing of the German political } \\ & \text { party Free Democratic party, a liberal and }\end{aligned}$


conservative party. Works on human rights,

press freedom and democracy

Heinrich Böll Stiftung (HBS)

NGO

Development wing of the German political party the Green Party (Alliance 90). Office established in Tunisia in 2013.

Friedrich Ebert Stiftung (FES)
NGO

\section{Development wing of the German Social}

Democratic Party, a centre left party. Office established in Tunis in 1988. Supports syndicate structures and women and youth involvement. Cooperation with UGTT since the

1960s. Its North Africa programme focuses on social security, the informal sector,

environment and climate.
Le Forum Tunisien pour les
Droits Economiques et

Sociaux (FTDES)

\section{NGO}

\section{Tunisian non-profit established in 2011} Neutral, independent of any political party and devoted to defending economic and social rights. Works on women's rights, economic rights and migrants' rights.
Involved as an organizer of the water protests in Redeyef and as mediator between protestors, CPG and SONEDE. 
Involved as

coordinators,

mediators, facilitators

in other industrial and

economic disputes.

\section{La Ligue tunisienne des droits de l'homme (LTDH)}

Founded in 1976 and remains the doyenne of human rights organisations in Tunisia with additional focus on civil and political rights, immigration, youth, and freedoms of association and expression.
Large human rights advocacy footprint.

One of the four

constituent members

of the National

Dialogue Quartet.

\section{Association Ichkeul pour la Veille Stratégique \\ Développement Durable et \\ Environnement (AIVSDDE)}

NGO

\section{Focuses on environmental conservation in the} Ichkeul basin. Carries out research,

coordinates between

\section{Peace Lab Tunisia}

Project

Established a country-wide network of youth 'peace labs' with labs in Mednine, Kasserine,

Bizerta and Sidi Bouzid 
Attalaki Pour la liberté et l'égalité

Founded by a group of Tunisian youth from different religious minorities in 2016.

Defends freedom of belief and religion.

Facilitates the voice of religious minorities be heard. Develops culture of dialogue and communication. Works citizenship among young people. Contributes to interfaith dialogue and peaceful coexistence.
Held the first meeting on religious freedom within a church in Tunisia and the Arab world and the first Round table of

Tunisians from different religions and faiths (Imams of Muslims, Christians, Jewish, Baha'is, professors from the University of Zaytouna and Ibadi, Shiites and non-believers). The meeting was an opportunity to break stereotypes, especially about Tunisians of Muslim background who have converted to another religion.

Organized many meetings with the participation of speakers from Egypt, Canada, Tunisia, UK and Italy on various topics related to religious freedom, 
religious and cultural diversity, pluralism, women, journalism, racial discrimination, migration, human rights and citizenship.

Issues an annual report on religious freedom in Tunisia 2020 was issued, which is the first in Tunisia and the Arab world in its form and content.

L'Association Tunisienne de Soutien des Minorités
NGO

\begin{abstract}
A non profit working on minorities' rights religious, cultural, ethnic, social and sexual. Supports values of diversity and co-existence. Advocates politically for minorities. Carries out grassroots activities and raises awareness of the historical role of minorities.
\end{abstract}

In partnership with KAS, has taken part in interreligious focus groups (2018) and roundtables including on coexistence in education (2021). Ran a seminar on building a culture of peace with Tunisian Jewish, 
Muslim and Christian

leaders (2019)

\section{Association ADO+}

Non-profit founded in 2011 focusing on civic education among youth. Advocates for children and youth rights. Supports youth artistic expression, offers a space for youth to be together.
Conducted the project 'Building alternatives for and with youth at risk of social rupture and radicalisation in partnership with the French NG Santé Sud. Offers an online space that gives information on all the projects and programmes that work with youth, including a question/answer function around radicalization, prevention of all forms of violence against children and youth.

Recently ran a session 
called 'Elles

maintenant' in

partnership with

international NGOs on

the empowerment of

women.

$\begin{aligned} & \text { Association pour la } \\ & \begin{array}{l}\text { Promotion du Droit à la } \\ \text { Différence }\end{array} \\ & \text { NGO }\end{aligned} \quad \begin{aligned} & \text { Founded in 2011, a non-profit working on } \\ & \text { diversity. Works on freedom of expression and } \\ & \text { minorities' rights. }\end{aligned}$
$\begin{aligned} & \text { Observatoire pour la } \\ & \text { defense du droit à la } \\ & \text { difference, which } \\ & \text { coordinates between } \\ & \text { groups vulnerable to } \\ & \text { discrimination, civil } \\ & \text { society and state } \\ & \text { bodies (see below). }\end{aligned}$

\begin{abstract}
Observatoire pour la
défense du droit à la

difference (O3DT)
\end{abstract}

Network of associations Network linking 72 associations working

against discrimination in Tunisia, with women,

children, ethnic minorities, religious minorities,

sexual minorities, autochthonous populations,

less abled people, people with HIV and

migrants. Advocates for legal changes for the

protection of minorities. Carries out cultural

initatives, builds capacities of its member

associations. 


\section{Association Femmes}

Jeunes et Enfants

NGO

Non-profit supporting marginalized women,

based in Jenouba, created in 2013. Works on

children's and gender rights, youth and sport.
L'association Voix libre des femmes de Tataouine
NGO
Regional non-profit working in Tataouine, politically independent. Works on civic awareness among women and girls in

Tataouine, especially rural dwellers, through education and training. Supports women to become part of economic, political and social transformation. Combats violence against women, supports women to be involved in public institutions. Raises awareness about the role of women in education and citizenship.
Organizes conferences and seminars. Carries out training to help women build revenue streams. Participates in the identification of state projects to help women. Partners with state institutions 
Established in Sfax in 2013 by a group of youths, working on youth participation at local, regional and national level. Focuses on

addressing violence, extremism and helping

youth resolve conflict through dialogue. 